$12-29-2017$

\title{
Efforts to increase Carica Dieng superior drink products through Improvement of production and marketing system to achieve local economic potential
}

\author{
Inaki Maulida Hakim \\ Universitas Indonesia, inakimaulida.hakim@yahoo.co.id \\ Wuri Listiani \\ Universitas Indonesia
}

See next page for additional authors

Follow this and additional works at: https://scholarhub.ui.ac.id/ajce

Part of the Social and Behavioral Sciences Commons

\section{Recommended Citation}

Hakim, Inaki Maulida; Listiani, Wuri; and Adiweno, Latu (2017). Efforts to increase Carica Dieng superior drink products through Improvement of production and marketing system to achieve local economic potential. ASEAN Journal of Community Engagement, 1(2).

Available at: https://doi.org/10.7454/ajce.v1i2.84

Creative Commons License

(c) (i) (2)

This work is licensed under a Creative Commons Attribution-Share Alike 4.0 License.

This Research Article is brought to you for free and open access by the Universitas Indonesia at ASEAN Journal of Community Engagement. It has been accepted for inclusion in ASEAN Journal of Community Engagement. 


\title{
Efforts to Increase Carica Dieng Superior Drink Products Through Improvement of Production and Marketing System to Achieve Local Economic Potential
}

\author{
Inaki Maulida Hakima*, Wuri Listiania, Latu Adiwenoa

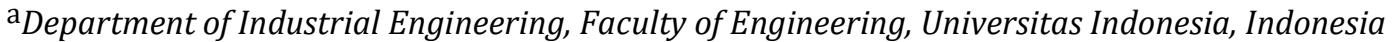

Received: October 20"th 2017 || Revised: November 9th \& November 19th 2017 || Accepted: November $29^{\text {th }}, 2017$

\begin{abstract}
Dieng is a plateau in Central Java Province where most of the land is utilized for agriculture. People cultivate potatoes and horticultural plants as the main commodities. Besides, they also began to cultivate fruit crops, carica. The cultivation and utilization of carica is a form of Dieng plateau area erosion conservation. For the past few years, carica has begun to be produced as a variety of processed foods and drinks, such as jam, sweets, chips, and carica syrup. Our partners in the Community Engagement Grants program here is a collection of home industries in the field of carica drink which is then named as Carica Dieng Production House (CDPH). One of the problems faced by this industry lies in the production system. Also, this community experienced a loss of opportunity due to the media for marketing. This Community Engagement Program aims to improve the process. Improvements are divided into several aspects, such as product innovation, manufacturing process improvement, financial planning and accounting, and marketing. Improvements in the waste disposal system are also made. The methodology that we used in this paper is divided into three main areas, namely pre-action phase, core phase, and monitoring and evaluations. The output of this activity is to make a good product in all aspects of the process. All of this cannot be separated from the main goal in creating superior products that can compete in national and global markets.
\end{abstract}

Keywords: Carica; Social Entrepreneurship; Small Medium Enterprises Improvement; Marketing System; Production System

\section{Introduction}

CDPH empowers Dieng community who major income previously was from farming during the growing season. According to Khanifa (2015), the existence of CDPH is also useful as an act of revitalization. The cause of revitalization does not replace the main economic activity of the citizens, but rather provides additional income for farm households and small and medium-sized micro enterprises through the CDPH. The Patak Banteng-Dieng village, Kejajar Wonosobo District, namely the main village for the city of Dieng because it has quite a lot of tourist attractions and there are also national-scale events annually. From a brief survey conducted found that in the Patak Banteng village, the majority of the population's net income is from carica production, there are about 20 $\mathrm{CDPH}$ that produce syrup carica. Carica production becomes quite important for the people of Dieng because carica is one of the specialties of Dieng and it can attract tourists to keep coming.

According to Widyastuti (2008), the planting and utilization of carica is a form of conservation that is suitable in hilly topography area to mountainous area with a relatively large slope of land with high erosion potential. The intercropping land use between potatoes and carica can lower the rate of soil erosion and increase the productivity of both crops, carica and potatoes. Carica is not a seasonal fruit that is easy to be cultivated, but, the utilization of this fruit is still less than optimal. A considerable number of problems are found, among which caricas are discarded at harvest time because submaximal processing capacity. The members of the CDPH association are

*Correspondence Author: inakimaulida.hakim@yahoo.co.id 
farmers and entrepreneurs with little to no educational background in business and industry.

a.

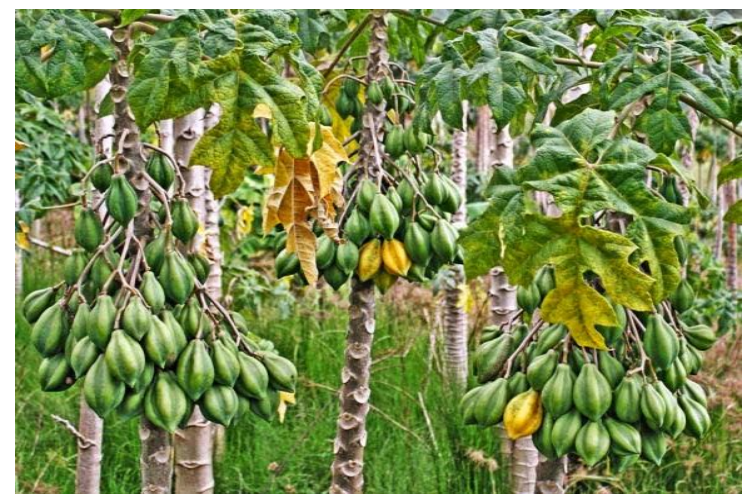

b.

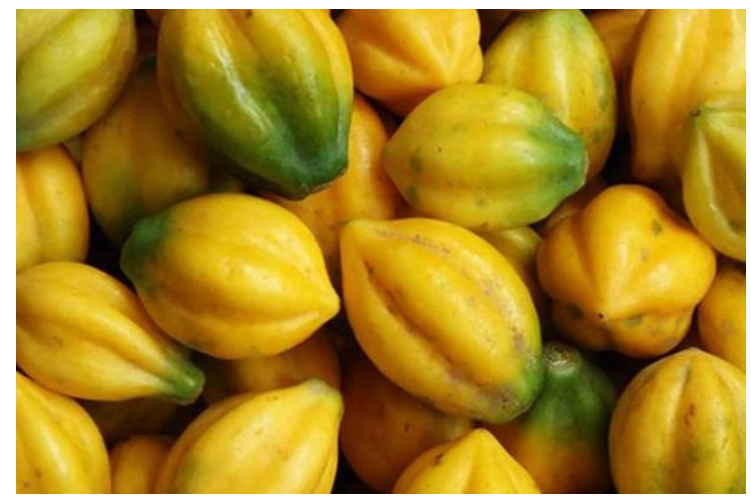

Fg. 1 (a) Carica Plant; (b) Carica Fruit Source: satyawinnie.com

To generate superior carica products that can compete in the markets, som problems still need to be solved. The main issues are related to marketing, product quality, financial knowledge. Ideally, the production of a superior product should have a balance of economic, social, and environmental (Hakim and Annisa, 2016). The product must be of good quality and environmentally friendly. Also, product marketing strategy in the era of globalization is getting tighter. Entrepreneurs in the field of SMEs should be able to compete using the development of technology in marketing their products. Besides, knowledge in finance is needed so that the business can continue to grow and not stagnated.

From the survey conducted to find the real condition, 20 CDPH produce carica syrup with taste and packaging are relatively the same, and the original version is made by adding sugar into carica fruit with plastic cup packaging in Figure 2. Besides the relatively same products between $\mathrm{CDPH}$, the marketing system they apply is only personal selling (face to face to the customer) and printed advertisement (pamphlet/banner), they didn't use any online advertisement to promote the carica products so that few people outside the Dieng city know about the product. Another problem is short expiration time. So, it is rarely production house makes the big capacity of production. In other words, the production process of carica product still not optimal. There is no standard dosage of the product, SOP standards, maintenance schedule, etc. This loss is because the carica syrup is only marketed in the tourist area of Dieng and it cannot last long because the product does not use sufficient preservatives. 


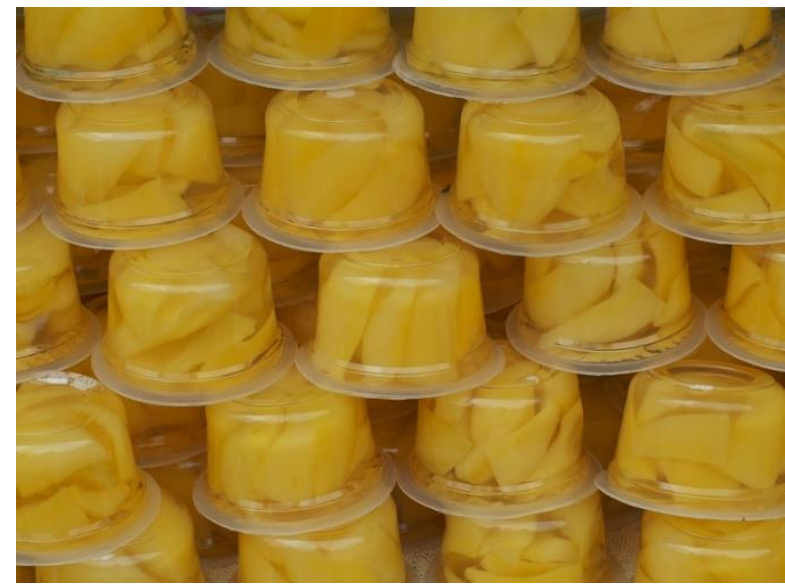

Fg. 2 The Original Version of Carica in Syrup Source: satyawinnie.com

Despite the aforementioned drawbacks, the association of CDPH deems carica fruit has a good opportunity to be further developed. As a tourist attraction, Dieng is visited by a significant number of local and foreign tourists. According to Kurnia (2015). Benefits from the economic activities of the tourism sector Dieng Plateau provides benefits for business unit managers. A contribution of tourist income (Kp) of 35\% and contribution of tourism to household expenditure (CW) equals 6.46\%. By using threshold or limit for classification in the contribution of tourism income, household income of business actor is low (25\% until 49\%). Viewed from the contribution of tourism to household expenditure which only amounted to $6.46 \%$, which is considerably low. This can increase if the business unit managers make innovations to enhance the attractiveness for tourists. Therefore, this community collaboration grant proposal is intended to contribute to the solution the problem of CDPH association in particular.

The research of this community engagement program is a continuation of community service program in 2016 where initially the concept of community engagement program was obtained from interview and observation to the partners of CDPH. This event resulted in the conclusion that in order to promote Carica as the original local product of Dieng that can compete with large factory beverages that have been marketed on a national scale, Carica Dieng Production House must embrace a business strategy that involves industrial engineering scholar become one of the keys to the success of a business.

The success of a community engagement program cannot be achieved instantly with one program but must improve methods used in all lines of Business Process for the significant impact of the program. It is, therefore, necessary to have measurable sustainability that suits the needs of partners.

Previous research by Hakim and Annisa (2017) in the International Conference on Education, Business, and Management entitled "Key Performance Indicators to Achieve Sustainability in Carica Micro Enterprises in Wonosobo Dieng" concluded that there are still many factors to be improved for carica products Dieng to be able to compete globally and sustainably. Table 1 below shows the Key Performance Indicators (KPI) scores from Dieng search industry home. From Table 1 we can see to get KPI for sustainable business has three perspectives. They are economic, social and environment. The three factors (economic, social, environmental) divided into fifteen indicators which are identified and comes from the literature. A total of eight owners of carica micro enterprises rate the importance of each KPI level. A Likert scales ranging from 1 to 5 was used to indicates the perspectives of the owner about the importance of the KPIs. The average of the 
importance values is presented in Table I. From this research indicators environment is becoming the focus. Two indicators are removed from the list due to the low importance of the KPIs, and the rest of the thirteen indicators are proposed as the sustainable business KPIs of Carica microenterprise.

Table 1. Score KPI of Carica Dieng Production House

\begin{tabular}{clc}
\hline Perspectives & \multicolumn{1}{c}{ Indicators } & Mean \\
\hline \multirow{4}{*}{ Economic } & Increase profitability & 4.875 \\
& Increase product sales & 5 \\
& Product innovation & 4.75 \\
& Incident investment & 4.5 \\
& Increase IT usage & 4.5 \\
& Employee satisfaction & 4.625 \\
& Product quality & 4.875 \\
& Employee welfare & 4.75 \\
& Customer satisfaction & 4.875 \\
& Increase quality of information system & 4.875 \\
& Number of injuries & 4.5 \\
& Electricity cost & 4.125 \\
& Total waste & $\mathbf{2 . 6 2 5}$ \\
& Use of equipment and raw materials & 3.875 \\
& Customer perception about environmentally-friendly & 4.875 \\
& image &
\end{tabular}

Source: Hakim and Annisa, 2017

The problems faced by partners to develop carica beverage business is related to the production system that has not yet had a Standard Operational Procedure (SOP) and good layout system in carica making process. Also, accounting of financial records that are still done manually and mixed with other businesses or household finances, so there is no financial history of the business they run. Moreover, partners have not been able to determine the profit of planned production targets. Also, the cash flow has no recorded history, which resulted in the partners being unable to determine financial decisionmaking for their business. Another problem is digital marketing that has not been conducted optimally. Therefore, in this community engagement program, we made Technological and Scientific application with the aim to create social media accounts and website to be able to develop carica home production business carica.

Technological and Scientific application at CDPH is intended to empower the potential in society and solve the problems faced by CDPH. Hence, the existence of this program is expected to improve the prosperity and economy of local people who work as carica syrup producers.

Besides, Technological and Scientific applications are used to help promote carica in syrup products to expand their market area. Developing the insights, knowledge, skills, and skills in carica syrup production to manage their financial systems and can assess the company's potential for generating profits. Encouraging partners to manage waste generated from the production process and turn it into something valuable to support the establishment of a clean production system. The result of Technological and Scientific implementation is: 
1) More productive improvement of the production process by using the application of industrial engineering science that consists of design methods that can minimize the cost of production, which include: layout redesign, maintenance production machine schedule, make Standard Operational Procedure (SOP) in the related production process to eliminate the 8 wastes of production, and reduced cycle time of making carica syrup.

2) Optimizing the product marketing system by designing a website that is by user experience to facilitate consumers to use and interested in e-commerce based website.

3) Creating financial statements using manufacturing accounting concepts and cost accounting. Bookkeeping system through Microsoft excel software is simple but applicable to help partners in calculating expenditures and income earned. Thus, through the income earned partners can make strategic decisions for the business.

4) Managing waste problems by creating a production system associated with waste disposal that does not pollute the environment and utilization of carica product by turning it into other products such as carica seed coffee and compost or fertilizer so that waste that has been disposed of can be a valued by-product.

\section{Theoretical Background}

\subsection{Marketing Concept}

Marketing is an overall system of business activities devoted to planning, pricing, promoting and distributing goods and services that can satisfy the needs of both buyers and potential buyers. The marketing concept says that the key to achieving organizational goals consists of determining the needs and wants of the target market and providing the desired satisfaction more effectively and efficiently than competitors. In marketing, there are six concepts that are the basis for the implementation of an organization's marketing activities, which are:

1. The Production Concept

The production concept argues that the consumers will love products that are cheap and available everywhere. This concept is oriented to production by exerting all efforts to achieve high product efficiency and wide distribution. The task of management is to produce as many items as possible because consumers are considered to be receiving widely available products with their purchasing power.

2. The Product Concept

The product concept says that consumers will love products that offer the best quality, performance, and characteristics. The task of management here is to create quality products because consumers are considered to love high-quality products in appearance with the best features. 


\section{The Sales Concept}

The sales concept holds that consumers, by being left alone, organizations must carry out aggressive sales and promotion efforts.

4. The Marketing Concept

The marketing concept says that achieving organizational goals consists of determining the needs and wants of the target market and delivering the expected satisfaction more effectively and efficiently than competitors.

5. The Social Marketing Concept

The concept of social marketing argues that the task of the organization is to determine the needs, wants and interests of the target market and to provide the expected satisfaction in a more effective and efficient way of competing societies while maintaining or enhancing consumer and community welfare.

6. The Global Marketing Concept

In this global marketing concept, executive managers seek to understand all the environmental factors that affect marketing through robust strategic management. The goal is to strive to meet the wishes of all parties involved in the company.

\subsection{Lean Manufacturing System Production}

According to Ahyani, what is meant by the production system is a combination of several units or elements that are interconnected and mutually supportive to implement the production process within a company. Some of these elements include company products, factory location, the location of production facilities, work environment of employees and production standards used in the company. In modern production systems, there is a process of value-added transformation that converts inputs into outputs that can be sold at market competitive prices.

Lean Manufacturing Principle comes from Japanese manufacturing industry. Lean is often defined as a tool that can help reduce waste of products, waste of costs, waste of time and so on. Lean explained that reducing waste can use Value Stream Mapping (VSM), 5S, Kanban, and Poka-yoke methods. According to Toyota, lean is not only equipment, but it can reduce three types of waste which is known in the Japanese Language are Muda (work that does not add value), Muri (excessive work) and Mura (imbalance) by finding the problem systematically.

According to Gaspersz and Fontana (2011), Lean is a continuous improvement effort to eliminate waste, and to increase the value added of products (goods and or services), to deliver results to customers (customer value). He also explained seven types of waste which are:

1. Overproduction: producing more than internal and external customer needs or producing faster than customer's time requirements. The cause is lack of communication, too much focus on the workload without considering customer needs.

2. Delays (waiting time): delay waiting for a machine, equipment, raw material, supplier, maintenance.

3. Transportation: moving material at great distances from one process to the next that can result in increased material handling time. The causes are a poor layout, lack of coordination in the process, poor housekeeping, poor workplace organization, multiple and long-distance storage locations (multiple and longdistance storage locations).

4. Skills: unequal employee abilities result in production line inhibition. Suboptimal workers utilization is one of the causes of waste skills because if the ability of 
workers does not match the task given, then the results of his work will not achieve satisfaction.

5. Processes: additional process or unnecessary or inefficient work activity. The causes are uncertainty in equipment usage, poor maintenance, failure to combine work operations.

6. Inventories: hiding problems and incur additional handling activities that should not be required. The causes are unreliable equipment, unbalanced flow, incapable suppliers, inaccurate forecasting, large batch sizes, and long changeover times.

7. Motions: a movement of a person or machine that does not add value to goods and services to be delivered to the customer, but only adds cost and time alone. The causes are a work method that is not a consistent, bad working layout organization.

8. Defect products: a reworking of products or defective products must be eliminated. The causes are Incapable processes, insufficient training, lack of standard operating procedures.

In conclusion, the types of waste can be known by the type of waste that occurred. The results of the analysis on the type of waste can help companies in identifying the types of waste that may occur in the company.

\subsection{Financial Statement System}

The financial statement is the financial information of a company in an accounting period that can be used to describe the performance of the company. Financial statement information is the result of a recording process, which is a summary of the financial transactions that occurred during the relevant fiscal year. Financial statement information is part of the accounting reporting process. According to Sofyan Syafri Harahap, the main Financial Statements contains:

1. A balance sheet that depicts the company's financial position on a given date.

2. Calculation of Profit and Loss that describes the number of results, costs, and profit/loss companies in a certain period.

3. Reports on sources and uses of funds for a period.

The purpose of financial statements is to provide information regarding the situation, performance, and changes in the financial position of a company that is beneficial to many users in decision making. The general purpose of the financial statements is mentioned as follows:

1. To provide reliable information about economic resources.

2. To provide reliable information about sources of net worth derived from business activities in the search for profit.

3. To assess the financial information that can be used to estimate the company's potential for generating profits.

4. To provide other necessary information about changes in assets and liabilities.

5. To disclose other relevant information required by users of the report. 
Inaki M. Hakim, Wuri L., Latu A. | ASEAN Journal of Community Engagement | Volume 1, Number 2, 2017

\subsection{Community Empowerment}

The interpretation of community empowerment is based on understanding the concept that the organizational domain is not absolute but instead serves as a departure point for further discussion on natural ways to determine and measure community empowerment as a process. The paper on community empowerment is seen as a step to clarify and create operational concepts to guide practitioners and empower the measure community in a program (Laverack, 2001). Therefore, it may be possible to measure the indicators before and after program Hakim and Annisa (2017) such as in aspects of social, economic and environment.

The process of community empowerment is defined by the last research (Wallerstein and Bernstein, 1988; Rissel, 1994; Swift and Levin, 1987). (UNDP,1995) explained that the process of enhancing individual, group, organizational or community capacity can be divided into several steps: (1) analyze their /environment, (2) identify problems, needs, issues and opportunities, (3) formulate strategies to deal with these problems, issues and needs, and seize the relevant opportunities, (4) design a plan of actiion, and (5) assemble and use efficiently and on a sustainable basis resources to implement, monitor and evaluate the plan of activities, and (6) use feedback to learn lessons

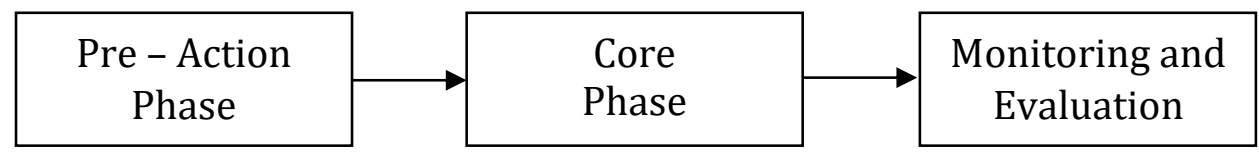

Fg. 3 Process of community empowerment that has be done by our team

The empowerment process in this paper is divided into three main areas, which areas are a pre-action phase, core phase, and monitoring and evaluations. The stages show the results achieved in each section so that a practice empowerment community can be controlled easily. The aspect indicators of an empowerment program like Hakim and Annisa (2017) are also more controlled by this division. The first stage, i.e., pre-action phase must be completed before entering the next stage. As a process that aims to succeed the program, the division into three main areas in this study serves as critical stages that must be assessed between practitioners and partners. Partners in this study were Carica Dieng Production House (CDPH).

\section{Methods}

In Patak Banteng Village the total of CPDHs is about 20. Although not all the CDPH are active, for this program, we take 10 Carica Dieng Production Houses that are actively developing beverage business carica.

Figure 4 describes the proposed milestone, so it is expected that the program's achievement after the 10 th month has reached $100 \%$. The program is scheduled to be implemented then stepped to the next stage of Monitoring and Evaluation. 


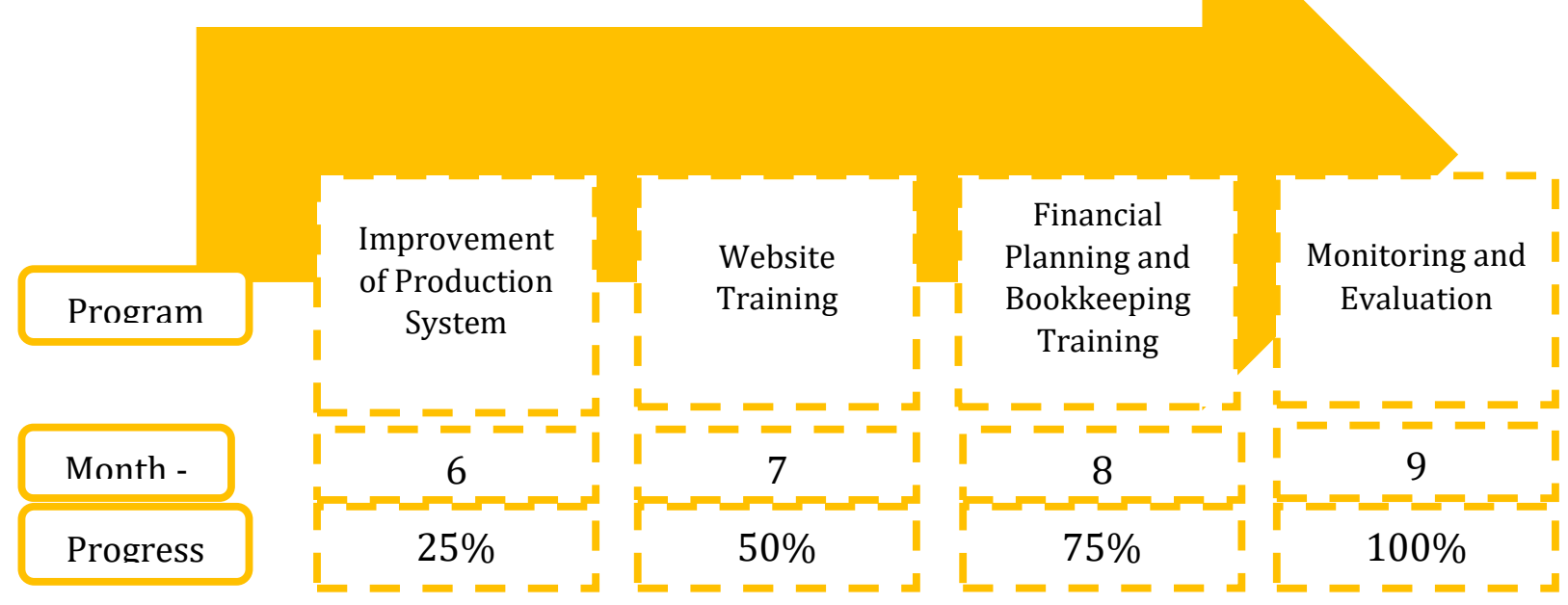

Fg. 4 Activity Milestones and Program's Targets

Implementation of this community service program will be run in 3 stages with the explanation as follows.

\subsection{Pre-Action Phase}

This stage is a preparatory stage before heading to the core program to be implemented. The pre-action phase includes:

a. Initial discussion with Carica Dieng Production House to determine the problem formulation and the expected outcome of the program.

b. Survey to Carica Dieng Production House in the field of production, bookkeeping management and application of marketing system, to know that the solution offered can be optimally applied.

c. Making permission with related parties.

d. Planning activities.

\subsection{Core Phase}

The core stage of the planned activities in community service consists of several pieces of training related to social business development efforts of Carica Dieng Production House with a focus on a production system, bookkeeping and marketing management. The table describes the training and the program, and its activities as well as the timeframe for its implementation.

Table 2. Program's Main Activity

\begin{tabular}{lll}
\hline \multicolumn{1}{c}{ Development Program } & & \multicolumn{1}{c}{ Activity(s) } \\
\hline Production Process & $\bullet$ & Create SOP standards for related production processes. \\
Improvement & - Create a layout system, maintenance schedule, SHE displays. \\
& - Provide counseling to relevant partners \\
& - Monitoring related production processes at home industry \\
& carica partner sites \\
\hline Marketing System & - Create a pocket book using the website caricadieng.org \\
Development & - Conduct training on the use of the website as a marketing \\
& & medium. \\
\hline
\end{tabular}


Inaki M. Hakim, Wuri L., Latu A. | ASEAN Journal of Community Engagement | Volume 1, Number 2, 2017

- Monitoring person in charge of website caricadieng.org to be skilled at updating and managing the website.

Financial System - Creating an applicable, easy-to-use and optimized template

Development and formulation template for Microsoft Excel in manufacturing accounting and cost accounting.

- Conducting training on the use of Microsoft Excel as a medium for financial bookkeeping of partners.

Evaluation and Competition - Hold a competition of programs that have been done and applied before.

\subsection{Monitoring and Evaluation}

This phase is intended to evaluate the activity program proposed above. The aspects assessed in this case are the result of the innovation and marketing system that has been implemented. The activities offered in monitoring and evaluation are as follows:

a. Periodic scheduling and oversight of programs.

b. Evaluate achievement targets with implemented results.

c. Evaluate the use of budgeted funds.

The three stages above focus on the outputs that can increase CDPH's revenue from the financial management, marketing systems, and production processes. With this method, it is expected to get the desired results according to the three categories. All improvements that have been made tailored to the capabilities of the people from Dieng City.

Improvements regarding production use several methods in lean manufacturing. There are three methods used in eliminating the source of waste in carica production, which are:

a). Standard Work

This technique seeks to create standards in all operational activities undertaken in the process of making carica products.

b). 5S (Housekeeping)

$5 \mathrm{~S}$ is the basic method to keep the production environment neat and clean. This is also done to maintain quality. This technique is done in several ways ranging from sorting unneeded tools, doing good placements, cleaning the environment, creating a good workplace standard, and making ways to keep the environment to always apply $5 \mathrm{~S}$.

c). Total Productive Maintenance (TPM)

TPM is a method used in maintaining the machine and equipment that will be used. The purpose of this technique is to ensure the availability of a tool at any time.

There are methods in understanding the marketing concept used. The first step is to identify the trends in the market and create marketing opportunities within it. This stage can be done merely by looking at the condition of several factors:

a). Competitor

Competitors can be an object in benchmarking to find what customers like. This benchmarking can be done on different products from we sell. However, the output we get from this process is the tendency that the customer wants and the potential opportunity that has the selling value.

b). Costumer

The customer is a direct object to determine the trend. This can be done by conducting interviews or surveys to the customer. Obviously, this is done by 
taking samples from some people who will represent the market that we have now.

c). Social

The existing social conditions can be an insight for producers in seeing the current opportunities.

d). Technology

The development of technology will facilitate the operational activities of production. Thus, this can be an opportunity to gain a competitive advantage for entrepreneurs.

\section{Result and Discussion}

As a result, efforts to develop production and marketing systems give a considerable number of positive impacts especially for carica production house partners because it will help to optimize existing production process. Through the development of production system will also be conducted training to conduct financial planning and bookkeeping. Improvements in waste systems are also carried out to implement one of the product sustainability concepts. Also, the marketing system also became one of the focuses in this grant project. A good marketing system will help carica in syrup entrepreneurs to expand opportunities for buyers. Thus, buyers who want to get carica in syrup not only for those who were visiting the Dieng Plateau area. Planning and financial bookkeeping are also taught to record all transactions.

The initial stages of this community engagement are the pre-action phase. Surveys, discussions, and permission are our main agenda. During this stage, no significant problems occur as a result of the high commitment of CDPHs in conducting this activity.

Improvements in the production sector affect the quality and profits owned by the company. The production process that has been carried out involves the making of Standard Operating Procedures (SOP) in the manufacturing of carica. This SOP has successfully helped maintain the quality by making conventional raw materials that can be processed. Also, the new standard also emphasizes the lean manufacturing process by eliminating seven waste sources. The following is a list of improvement activities and their relation to the elimination of 7 waste.

Table 3. Waste(s) eliminated by activities

\begin{tabular}{cc}
\hline Activities & Type of Waste(s) \\
\hline Standard design of layout system & Motion, Transportation, Delays \\
\hline $\begin{array}{c}\text { Production and labor scheduling } \\
\text { templates }\end{array}$ & Skills, Defects, \\
\hline $\begin{array}{c}\text { Maintenance Schedule of carica } \\
\text { processing machine }\end{array}$ & Defects, Delays \\
\hline $\begin{array}{c}\text { Material Resource Planning / } \\
\text { Inventory raw material } \\
\text { Template of carica syrup }\end{array}$ & $\begin{array}{c}\text { Overproduction, over processing, } \\
\text { inventories, }\end{array}$ \\
\hline
\end{tabular}

Marketing activities attempt to change the view of CDPH in marketing their products. Previously, marketing was not a concern for CPDH as they only sold their product in their store. Currently, with the help of information technology, they try to broaden the marketing area. However, according to the basic concept of previous marketing in the literature study described above, it is explained that CPDH must first be able to determine product concept and value proposition or unique point that this product has. Through the 
explanation by the team, they realize what is the concept of the product and the opportunity in the product that can be a selling point. The idea of marketing that we then teach is how we can know the development of the market by utilizing technology. We are looking for the happening trend on the market. Technology closely related to this marketing is the use of websites and social media. We strive to provide such media usage materials as a tool to increase sales. Currently, they have a shared website and social media of each production house. This table describes how the activities of the marketing training and how the skill and knowledge obtained by the participants.

Table 4. Skill and Knowledge Acquired

\begin{tabular}{cc}
\hline Marketing Activities & Skill and Knowledge Acquired \\
$\begin{array}{c}\text { Concept and the value } \\
\text { proposition of the product }\end{array}$ & $\begin{array}{c}\text { Now, CDPH realize what the value of } \\
\text { the product is, valuable parts in carica } \\
\text { plant, the bargaining point of the } \\
\text { product compare to others }\end{array}$ \\
\hline $\begin{array}{c}\text { Market and Trend research to } \\
\text { define opportunity }\end{array}$ & $\begin{array}{c}\text { They have the skill to read market } \\
\text { opportunity by seeing on consumer } \\
\text { behavior. They also can make an } \\
\text { innovation based on the trend }\end{array}$ \\
\hline $\begin{array}{c}\text { Use of Social Media and Website } \\
\text { in Marketing }\end{array}$ & $\begin{array}{c}\text { The ability to expand their market } \\
\text { with the help of technology }\end{array}$ \\
\hline
\end{tabular}

The making of financial bookkeeping has changed to become more systematic and more accessible in making decisions. Previous bookkeeping system is done using ordinary books that record sales and purchase of materials. This method is complicated in assisting calculations in decision making. Our team teaches how to create a simple bookkeeping system using Microsoft Excel. Bookkeeping in this way makes bookkeeping faster and more efficient in making decisions. It should be realized that the process of learning that each participant was different. However, our team overcame it by using proper knowledge management such as making simple guidebooks in operation.

Our next activity is holding monitoring and evaluation to get feedback from participants. Tracking in technical and learning process are routine. Also, control of the use of the budget is done so as not to have a deficit. The main activities in the evaluation are also conducted through the competition. This competition is a form output from learning process that has been done before. The competition has a theme in the innovation of carica waste side-product by looking at opportunities in the market. The production and marketing process is also explained by the participants. This competition produces a wide range of innovative products one of which is carica seed coffee and handcrafted souvenir from carica seed.

Based on the investigation of Hakim and Annisa (2017) in the International Conference on Education, Business, and Management entitled "Keywords Performance Indicators to Achieve Sustainability in Carica Micro Enterprises in Wonosobo Dieng." This community engagement program activities towards the pre-established KPI. This proves that the program is running in the right direction.

There is a social change in carica sales with a technological and scientific approach. Now, it is not just about selling carica drink. But, at this time they pay more attention to planning and systematics in selling. They become more sensitive to the environment to see the ongoing trend in the market. Also, the effects of technology use also encourage them to work with outsiders. 
An indicator of achievement in this community program has reached $100 \%$. In the future, it is hoped that by the conduction of the program, they will implement it consistently. So, they will get the increase of income especially for producers of carica production house in Bantak Banteng village. Because it has been two years, our team built and provided knowledge to local partners to work together to develop carica in syrup. In the table below describes the Input, Process, Output, and Outcome of community-related programs to establish the Carica drinks business in Dieng.

Table 5. Input, Proses, Output, and Outcome

\begin{tabular}{|c|c|c|c|}
\hline Input & Process & Output & Planned Outcome \\
\hline $\begin{array}{c}\mathrm{CPDH}, \\
\text { Industrial } \\
\text { Engineering, }\end{array}$ & $\begin{array}{l}\text { Production } \\
\text { System } \\
\text { Improvement }\end{array}$ & $\begin{array}{l}\text { - Standard design of layout } \\
\text { system } \\
\text { - } \text { Production and labor } \\
\text { scheduling templates } \\
\text { - } \text { Maintenance Schedule of } \\
\text { carica processing machine } \\
\text { - Material Resource Planning / } \\
\text { Inventory raw material } \\
\text { Template of carica syrup }\end{array}$ & $\begin{array}{l}\text { - Reducing production costs } \\
20 \% \text { of total } \\
\text { - Shorter production cycle } \\
\text { time }\end{array}$ \\
\hline
\end{tabular}

- Manufacturers of carica production houses can

$\begin{array}{cc}\text { CPDH, Web } & \text { Carica Website } \\ \text { Design } & \text { Caricadieng.org } \\ \text { Expert } & \text { Training }\end{array}$
market their products through the medium that has been taught.

- Have a pocketbook running the Caricadieng.org Website to market the product
- Increased sales of carica products $10 \%$

- One person proficient in operating Caricadieng.org

\begin{tabular}{|c|c|c|c|}
\hline $\begin{array}{l}\text { CDPH, Waste } \\
\text { Management } \\
\text { Expert }\end{array}$ & $\begin{array}{c}\text { Improvement on } \\
\text { Waste } \\
\text { Management }\end{array}$ & $\begin{array}{l}\text { Waste from Production does } \\
\text { not pollute the environment } \\
\text { - Waste can be utilized and has } \\
\text { more value } \\
\text { - Hygiene and safety display at } \\
\text { carica plant }\end{array}$ & $\begin{array}{l}\text { - Disposal of non- } \\
\text { environmentally harmful } \\
\text { production wastes } \\
\text { - } \begin{array}{l}\text { Cleaner production layout } \\
\text { - }\end{array} \text { Find useful carica waste by- } \\
\text { products }\end{array}$ \\
\hline $\begin{array}{c}\text { CDPH, CDPH } \\
\text { Expert }\end{array}$ & $\begin{array}{c}\text { Financial } \\
\text { Planning and } \\
\text { bookkeeping } \\
\text { Training }\end{array}$ & $\begin{array}{l}\text { - The ability to plan to } \\
\text { improve corporate strategic } \\
\text { decisions } \\
\text { - Simple Bookkeeping System }\end{array}$ & $\begin{array}{l}\text { - } \text { Create appropriate } \\
\text { business planning and } \\
\text { develop strategic plans } \\
\text { - Having a ready-made excel } \\
\text { program template that can } \\
\text { record financial data from } \\
\text { the carica business }\end{array}$ \\
\hline
\end{tabular}


a.

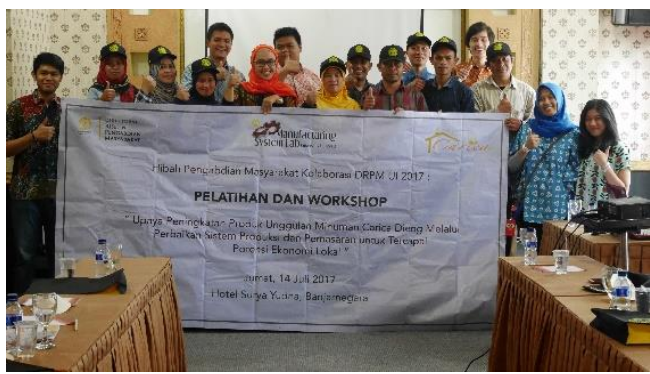

c.

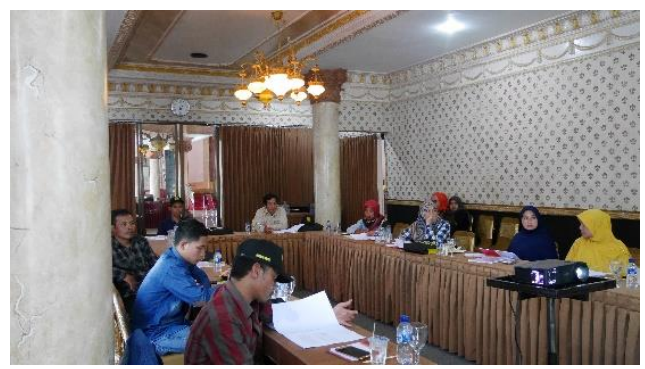

b.

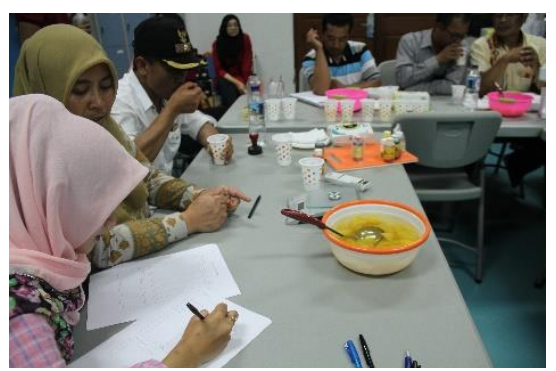

d.

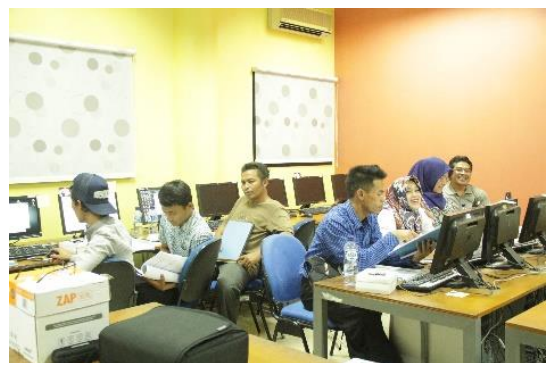

Fg. 5 (a), (b), (c), (d) The Training and Workshop Activities

The outcomes that were successfully performed from the previous plan included $80 \%$ actualized. Although one outcome was not achieved regarding quantity targets, there is still an increase in the consequences that have been planned previously. These outcomes are related to the rise sales and decreased production costs. While the figure has not reached the target as it is still in the range of $5 \%$ the outcomes are satisfactory for both the participants and the team.

Through an interview with the participants, this program received a very positive response. Their view of carica drinks is not just selling a product. There is a unique value owned by Carica that is not found elsewhere. They believe that this is their first step to continue developing the product and will make the Carica an icon of this area. This stance is not without a basis, as after a few months of training, there is an increase in sales due to the new product they launch. In the future, they will invite more local people to become entrepreneurs in the field of processed carica.

If we talk about whether these improvements can help them comprehensively, then the answer is a yes. Carica is one of the icons of this village. Carica cannot grow anywhere else. Thus, the surrounding community utilizes and make Carica as a natural resource that has particular selling value for them. However, today they are still producing this product using a simple production concept. Thus, their chances of competing with other regional superior products are becoming smaller. Moreover, many regions are starting to continue to develop excellent products in line with the increasing number of tourists within their region.

Now that we know that carica is hope for this village, we need concrete steps to make that happen. Through a variety of new improvements, this step is perceived as an initiative in developing this product. Hopefully in the future, with this improvement, more steps will constantly be taken by local people. An increase in the number of people's participation is also desirable. The greater number of participants will promote this village as a village that has the hallmark of superior quality Carica products.

After this activity took place, our team keep in touch with the participants. Our strategy step in keeping this all out is by monitoring and communicating with certain time limits 
until they can independently implement what they have learned before. Every three months we ask about their development conditions. Then it can be a feedback for them to keep running production in accordance with what has been taught.

\section{Conclusion}

Community Engagement Program is expected to be able to provide knowledge and independence for partners in developing carica syrup business so that it can be sustainable to face the global economic competition and able to grow the local economy. The list below is the achievement of our activities:

a. Strengthening partners to optimize the use of the website caricadieng.org and proficient in operating it for websites and social media accounts that have been created in the previous program can increase revenue.

b. Having a measurable and more efficient production system method that can reduce production costs. Partners can also understand how important it is to make continuous improvement in their respective home production.

c. Partners have a financial system that can support strategic decisions for business development.

d. Having a creative idea to innovate carica products made from carica fruit waste so it becomes a new product that has added value and can be sold in the market.

\section{Acknowledgements}

The team would like to express gratitude to Directorate of Research and Community Engagement Universitas Indonesia (DRPM UI) for administering the Community Engagement Grant funding scheme under grant number 2128/UN2.R3.1/HKP.05.00/2017, and Faculty of Engineering Universitas Indonesia (FTUI), Departement of Industrial Engineering for their initiative, contribution, and commitment in the program. Our highest appreciation also goes to Manufacturing System Laboratory, Industrial Engineering Faculty Universitas Indonesia (FTUI) Colleagues and Students for the unconditional and extensive support for the program. Finally, our sincere gratitude to the community in Carica Dieng Production House (CDPH], and Local Government of Wonosobo Regency for their cooperation during the program.

\section{References}

Achanga, P., Shehab, E., Roy, R., \& Nelder, G. (2006). Critical success factors for lean implementation within SMEs. Journal of Manufacturing Technology Management, $17(4), 460-471$.

Ahyani, Agus. (1992). Production Management and Production Planning. $4^{\text {th }}$ Edition BPFE, Yogyakarta

Brennan, M. A., \& Israel, G. D. (2008). The power of community. Community Development, 39(1), 82-97.

De Lange - Ros, E. and Boer, H. (2001). 'Theory and practice of continuous improvement in shop - floor teams', International Journal of Technology Management, Vol. 22, No. 4, pp.344-358.

Gaspersz, Vincent and Avanti Fontana. (2011). Lean Six Sigma for Manufacturing and Service Industries. Vinchristo Publication, Bogor. 
Inaki M. Hakim, Wuri L., Latu A. | ASEAN Journal of Community Engagement | Volume 1, Number 2, 2017

Gunasekaran, A. 1998. Implementation of productivity improvement strategies in a small company. Technovation page 311-320.

Hakim, Inaki and Annisa, Putri Nur Bahri. 2016. Key Performance Indicators to Achieve Sustainability in Carica Micro Enterprises in Wonosobo Dieng. International Conference on Education, Business, and Management (ICEBM).

Harahap, Sofyan Syafri. (2013). Critical Analysis for financial report. , $11^{\text {st }}$ Edition. Rajawali Pers, Jakarta.

Inaki Maulida Hakim and Annisa Putri Nur Bahri. 2017. Key Performance Indicators to Achieve Sustainability in Carica Micro Enterprises in Wonosobo Dieng. International Conference on Education, Business, and Management (ICEBM).

International Conference on Knowledge Management and Knowledge Technologies. ACM, New York, NY.

Jeroen de Mast and Joran Lokkerbol. 2012. An Analysis of the Six Sigma DMAIC Method from the Perspective of Problem Solving. International Journal of Production Economics 139(2), 604-614.

Khanifa K. Nurma. 2015. Revitalisasi Kemandirian Desa Melalui Adat Masyarakat Dieng di Dalam Kegiatan Home Industry Carica Perspektif Hukum Bisnis Syariah. Yogyakarta: Universitas Islam Negeri Sunan Kalijaga.

Kurnia, Rizki. 2015. Kajian Nilai. Dampak and Manfaat Ekonomi Kawasan Wisata Dataran Tinggi Dieng Jawa Tengah. Departemen Ekonomi Sumberdaya and Lingkungan. Bogor: Fakultas Ekonomi and Manajemen Institut Pertanian Bogor.

Laverack, G. (2001). An identification and interpretation of the organizational aspects of community empowerment. Community Development Journal, 36(2): 40-52.

M. S., Thampi, T. G., Dalvi, D. S., Srinivas, B., \& Patil, T. B. 2012. Enhancing waste reduction through lean manufacturing tools and techniques, a methodical step in territory of green manufacturing. International Journal of Research in Management and Technology, 2(2), 2249 - 9563.

Murphy, M. (2002). OECD small and medium enterprise outlook. Paris: Organisation for Economic Co-operation and Development.

Rissel, C. (1994). Empowerment: The holy grail of health promotion. Health Promotion International, 9(1): 39-47.

Rizki. Kurnia. 2015. Kajian Nilai. Dampak and Manfaat Ekonomi Kawasan Wisata Dataran Tinggi Dieng Jawa Tengah. Departemen Ekonomi Sumberdaya and Lingkungan. Bogor: Fakultas Ekonomi and Manajemen Institut Pertanian Bogor. 
Stockdale, R., Ahmed, A., Scheepers, H., 2012. Identifying business value from the use of social media: an SME perspective. In: Proceedings of Information System Innovation in Pacific Asia, Pacific Asia Conference on Information Systems (PACIS), 11-15 July, Ho Chi Minh City, Vietnam.

Swift, C. and Levin, G. (1987). Empowerment: An emerging mental health technology. Journal of Primary Prevention, 8(1-2): 71-94.

UNDP (1995). Capacity Development for Sustainable Human Development: Conceptual framework and operation signpost. New York: United Nations Development Programme.

Velazques, P., 2011. How Social Media Helps to Lower the Cost of Marketing. October 18, 2011. Retrieved from: https://www.dreamgrow.com/how-social-mediahelps- tolower-the-cost-of-marketing/ (accessed on 11.18.15).

Wallerstein, N. and Bernstein, E. (1988). Empowerment education; Freire's ideas adapted to health education. Health Education Quarterly, 15(4): 171-186.

Weller, K., 2016. Trying to understand social media users and usage: the forgotten features of social media platforms. Online Inf. Rev. 40 (2), 256-264.

Whitler, K.A., 2014, July 17. Why Word Of Mouth Marketing Is The Most Important Social Media. Retrieved October 19, 2016, from http://www.forbes.com/sites/

Widiastuti. Indri. 2008. Diversifikasi Tanaman Budidaya Carica Papaya di Dataran Tinggi Dieng untuk Konservasi Lahan. Pascasarjana Program Studi Biosains.. Surakarta: Universitas Sebelas Maret Surakarta

Zeiller, M., Schauer, B., 2011. Adoption, motivation and success factors of social media for team collaboration in SMEs. i-KNOW11. In: Proceedings of the 11th

[Photograph of The Original Version of Carica in Syrup (2013). Retrieved from http://www.satyawinnie.com/2013/07/carica-buah-cantik-rasa-unik-daridieng.html 